JOURNAL OF AWARENESS

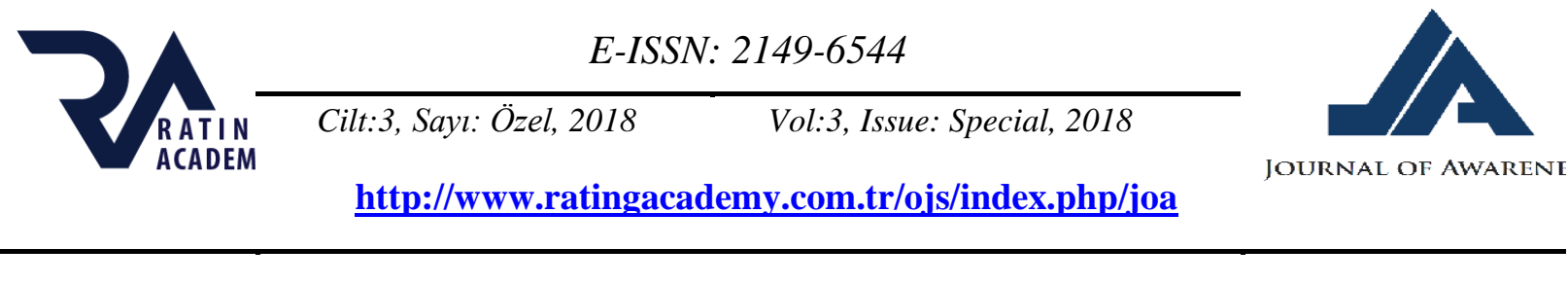

ARAP-ISRAIL SORUNU ve BÖLGESEL YANSIMALARI

THE ARAB-ISRAEL PROBLEM and ITS REGIONAL REFLECTIONS

\author{
Nigar Neșe KEMIKSIZZ \\ ANKA Enstitüsü Onursal Başkanı, Ankara/TÜRKIYE \\ E-mail:n.kemiksiz@ankaenstitusu.com
}

\section{MAKALE BİLGISI}

Anahtar Kelimeler:

İsrail, Filistin, Ortadoğu,

Balfour Deklarasyonu

\section{DOI:}

10.26809/joa.2018548623

\section{ÖZET}

Arap-İsrail sorunu, Birleşmiş Milletler'in Filistin'i taksim kararının ardından 1948'de kurulan İsrail devletine karşı Arap ülkelerinin savaş açmasıyla başlamış görünmekle birlikte, temeli 1917'de Balfour Deklarasyonu'yla Filistin'de bir "Yahudi milli yurdu" kurmayı taahhüt eden İngiltere'nin Birinci Dünya Savaşı sonrasındaki Ortadoğu politikalarına dayanmaktadır.

Filistin sorununun ilk evresi, Yahudilerin Yahudi milli yurdunu kurma, Arapların da bunu engelleme mücadelesi etrafinda 1948'e kadar sürmüs ve İsrail devletinin kurulmasıyla neticelenmiştir. 1948'den sonraki evre ise Israil ile Arap devletleri arasındaki savaşlar ve sonuç getirmeyen barı̧̧ giriş̧imleriyle şekillenmiş̧tir.

Arap-İsrail sorunu; 1948, 1967 ve 1973 'te üç büyük savaşa, Filistin ve Arap topraklarının işgaline, yurtlarını kaybeden Filistinlilerin mülteci durumuna düşmesine yol açmış, bölgede kamplaşmalar yaratmış, silahlanmayı arttırmış, radikalizmi güçlendirmiş, büyük güçlerin bölgeyi nüfuz alanlarına bölmesine zemin hazırlamuştır.

Bu çallş̧ada, Arap-İsrail sorununun temellerinin ve barış̧̧ çözüme ulaşılamamasının nedenlerinin ortaya konması amaçlanmakta ve 1917'den günümüze kadarki tarihi süreç, uluslararası ve bölgesel arka plan da dikkate alınmak suretiyle incelenmektedir.

\section{ARTICLE INFO}

Keywords:

Israel, Palestine, Middle East, Balfour Declaration

\section{ABSTRACT}

Although the Arab-Israel problem seems to start as a result of the declaration of war by Arab states against the state of Israel founded in 1948 following the United Nations partition resolution for Palestine, its origins go back to the post World War I Middle East policies of the Britain, which committed, with the Balfour Declaration of 1917, to establish "a National Home for the Jewish People" in Palestine.

The first stage of the Palestinian problem lasted in the form of the efforts by the Jews for establishing for the National Home for the Jewish people and the struggle by Arabs to prevent this from happening until 1948, which resulted in the foundation of the state of Israel. The stage after 1948 was shaped by the wars between Israel and Arab states and futile peace initiatives.

The Arab-Israel problem brought about three major wars in 1948, 1967 and 1973, as well as the occupation of the Palestinian and Arab territories, resulted in 


\section{DOI:}

10.26809/joa.2018548623
Palestinians losing their homeland and thus becoming refugees, created polarizations, increased armament, strengthened the radicalism in the region and paved the way for the great powers to divide the region into spheres of influence. The present study aims to find out the roots of the Arab-Israel problem and the reasons why no peaceful solution has been able to be found for the problem, and it examines the historical period from 1917 until today by taking the international and regional background into consideration as well.

\section{GíRiş}

Arap devletlerinin Filistin'i kurtarmak ve İsrail devletini yok etmek amaciyla 1948'de İsrail'e savaş açmalarıyla başlayan Arap-İsrail çatışmasının temelini Filistin sorunu oluşturmaktadır. Bu sorunun kökeninde, İngiltere'nin Birinci Dünya Savaşı sonrasında Ortadoğu'da stratejik çıkarları açısından önem taşıyan Filistin'i kontrolü altına alma amacı yatmaktadır. Siyonistlerin Filistin'de Yahudi devleti kurma hedefleri ile İngiltere'nin Filistin'e egemen olma arayışının çakışması, Filistin'de bir Yahudi milli yurdu kurma taahhüdünü içeren Balfour Deklarasyonu'na giden yolu açmıştır. Balfour Deklarasyonu'yla gerekli zeminin hazırlanarak İngiliz manda idaresinin kurulması, Filistin'de Yahudi milli yurdunun tesisine yönelik politikaların uygulanmasını sağlamıştır. Bu şekilde başlayan Filistin sorununun ilk aşamasını, Birinci ve İkinci Dünya Savaşları arasındaki çalkantılı dönemde manda topraklarında çoğunluğu oluşturan Filistinli Araplar ile Filistin'e göç eden Yahudiler arasında çıkan çatışmalar oluşturmuştur. Birleşmiş Milletler (BM)'in taksim kararının ardından Filistin toplumunun çöküşü ve İsrail devletinin kurulmasıyla sonuçlanan bu aşamadan sonra Filistin mücadelesini Arap devletleri üstlenmiş ve 1948'den itibaren sorun Arap-İsrail çatışmasına dönüşerek devletlerarası ve çok boyutlu bir nitelik kazanmıştır. Arapların 1948 Arap-İsrail Savaşı'nda ele geçirdikleri Filistin topraklarında bağımsız Filistin devleti kurma yoluna gitmemeleri ve 1967 Arap-İsrail Savaşı'ndaki ağır yenilgileri, İsrail'in bütün Filistin topraklarına hakim olmasına ve Filistinlilerin sadece devletsiz değil, yurtsuz da kalmalarına neden olmuştur. 1967 savaşından sonra Filistinliler, Filistin Kurtuluş Örgütü (FKÖ) liderliğinde bağımsız bir mücadele anlayışı benimserken, Arap devletleri savaşta kaybettikleri topraklarını geri alma amacını ön plana çıkarmışlardır. 1973 Arap-İsrail Savaşı Arap devletlerine amaçlarını kısmen de olsa gerçekleştirme imkanı vermiştir. 1973'ten sonra topyekun bir Arap-İsrail savaşı yaşanmamış, Arap-İsrail çatışması 1982'den itibaren Lübnan sahasında yeni aktörlerle devam etmiştir. Filistin mücadelesi ise 1987'deki İntifada'dan sonra Filistin topraklarına taşınmış, 1993'te İsrail ve FKÖ'nün birbirlerini karşılıklı olarak tanıdığı Oslo Mutabakatı'yla yeni bir aşamaya girmiştir. Ancak Oslo'nun başarısızlığı, İsrail-Filistin barışına yönelik umutların giderek kaybolduğu, çatışma ve ayaklanmaların yeniden başladığı, Filistinliler arasında bölünmelerin yaşandığı bir sürece yol açacaktır.Arap-İsrail sorunu 1979'da İsrail-Mısır, 1994'de İsrail-Ürdün barışının sağlanmasıyla kısmen çözülmüş görünse de Suriye-Lübnan ayağında ilerleme kaydedilememesi, çok taraflı sorunların müzakere edilememesi ve her şeyden önce Filistin sorununun sürüncemede kalması nedeniyle bölgedeki iklimi olumsuz şekilde etkilemeye devam etmektedir.

Arap-İsrail sorununun temellerinin ve barışçı çözüme ulaşılamamasının nedenlerinin ortaya konulmasını amaçlayan bu çalışmanın ilk bölümünde, İngiltere'nin Birinci Dünya Savaşı sonrasındaki Filistin politikası ele alınmakta ve İngiltere'nin stratejik çıkarları ile Siyonistlerin Filistin'de Yahudi devleti kurma amaçlarının örtüşmesinin Filistin'in geleceğini şekillendirdiği vurgulanmaktadır. Üçüncü bölümde İngiliz mandası döneminde Filistinlilerin Yahudi milli yurdu kurulmasını önlemeye yönelik mücadeleleri ele alınmaktadır. $\mathrm{Bu}$ mücadelenin Filistinliler aleyhine sonuçlanması üzerine Filistin meselesinin sorumluluğunu Arap devletlerinin üstlendiği ve Arap-İsrail çatışmasının başladığı dönem, dördüncü bölümün 
konusunu oluşturmaktadır. Bu dönem; Ürdün-Mısır mücadelesinin Filistin'in bağımsızlığına yönelik etkileri, 1967 Arap-İsrail Savaşı'ndan sonra Filistinliler ile Arap devletlerinin arasında amaç farklılıklarının belirmesi, 1973 savaşının ardından Arap-İsrail çatışması ikinci plana düşerken, Filistin-İsrail çatışmasının ön plana çıkması ve İsrail'in 1982'de Lübnan'1 işgal etmesiyle Arap-İsrail çatışmasında yeni bir aşamaya girilmesi bakımından önem taşımaktadır. Arap-İsrail sorununu çözmeye yönelik barış girişimlerinin ele alınmasını takiben çalışma, istikrarsız bir güç dengesinin hakim olduğu mevcut konjonktürde ne Arap-İsrail ne de Filistinİsrail çatışmasının barışçı çözümünü beklemenin gerçekçi olmadığı değerlendirmesiyle son bulmaktadir.

\section{INGILTERE'NIN FILISTIN POLITIKASI}

Osmanlı İmparatorluğu'nun Birinci Dünya Savaşı'ndaki yenilgisi, Arap coğrafyasında köklü değişikliklere neden olmuş, savaşın galip güçleri İngiltere ve Fransa bu topraklarda kendi çıkarlarına uygun yeni bir bölgesel düzen kurmuşlardır. Bu düzenin yapı taşlarını oluşturan Mayıs 1916 tarihli gizli Sykes-Picot Anlaşması ve Kasım 1917 tarihli Balfour Deklarasyonu, Filistin'in geleceğini de şekillendirmiştir.

İngiltere, Sykes-Picot Anlaşması'yla Osmanlı topraklarını Fransa ile paylaşırken, Balfour Deklarasyonu'yla Yahudilere Filistin'de 'milli yurt' vaadinde bulunuyor, 1914'ten beri temas halinde olduğu Mekke Emiri Şerif Hüseyin önderliğindeki Arapların da Osmanlı İmparatorluğu'na ayaklanmaları karşılığında bağımsız Arap krallı̆̆ kurma hayallerini canlı tutuyordu. Şerif Hüseyin İngiltere'den, Türkiye'nin güneyindeki bazı iller ile tüm Arap yarımadası, Suriye, Lübnan, Ürdün ve Filistin'i kapsayan 'Büyük Suriye' ve Irak topraklarında Haşimi hanedanının başında olacağı bir bağımsız Arap Devleti/Imparatorluğu kurulmasını (Armaoğlu: 29) ve hilafetin Osmanlılardan Haşimi hanedanına geçmesini talep etmekteydi (Aruri, 1972). İngiltere ise "özel çıkarlarının bulunduğu" Irak konusunda taviz vermezken, Suriye konusunda kapıyı açık bırakmakta, Filistin konusunda da net bir tutum almaktan kaçınmaktaydı.

Sykes-Picot Anlaşması'yla, İngiltere'nin Araplara vaat ettiği Suriye ve Lübnan'ın Fransa'ya bırakılması (Anadolu'nun bir bölümü de Fransa'ya bırakılacak topraklar arasında yer alıyordu), İngiltere'nin, Irak ile Akdeniz'de küçük bir sahil dilimini alması, Filistin'de ise uluslararası yönetim kurulması kararlaştııılmıştı. İngiltere ve Fransa kendi nüfuz bölgelerinde bir Arap liderinin hükümranlığı altındaki bağımsız bir Arap Devleti veya Arap Devletleri Konfederasyonu'nu tanımaya ve desteklemeye hazır olduklarını da belirtmekteydi(Kürkçüoğlu, 1982: 102-103).

Kasım 1917'de açıklanan Balfour Deklarasyonu'nda ise İngiltere'nin Filistin'de Yahudi halkı için bir milli yurt tesisini uygun karşıladığı, ancak Yahudiler için yurt kurulmasının, bu ülkede yaşayan 'Yahudi olmayan toplumların' medeni ve dini haklarını ihlal etmeyeceği ifade edilmekteydi (Armaoğlu: 33).

Filistin'in, İngilizsömürgelerine, özellikle Hindistan'a giden yollar üzerindeki stratejik konumu nedeniyle, İngiltere bölgede kontrolü ele geçirmeyi hedeflemekteydi. Balfour Deklarasyonu, Filistin'de İngiliz hakimiyetinin sağlanması bakımından meşrulaştırıcı bir araç işlevi görecek, Deklarasyon'la Filistin'de Yahudi milli yurdu kurulmasının taahhüt edilmesi, bölgede İngiliz varlığını gerektirecek ve Fransa'yı Süveyş Kanalı'na komşu topraklardan uzak tutacaktı (Cleveland, 2015: 271). İngiltere'nin stratejik çıkarları, Filistin'de Yahudi devleti kurulmasını amaçlayan Siyonistlerin hedefleriyle uyuşmaktaydı.

Dünyanın farklı bölgelerinde çeşitli ülkelerin uyruğu olarak yaşayan Yahudilerin kendilerine ait bir devlet çatısı altında bir araya gelmeleri düşüncesi, yaşadıkları ülkelerde karşı karşıya kaldıkları baskı ve ayrımcılıkla yakından bağlantılıdır. 1800'lü yıllarda Rusya'da 
Yahudilere karşı başlayan katliamlar, Siyonist hareketin doğmasında önemli rol oynamıştır. Siyonizmin ideolojik temelini 1896'da yazdığı Yahudi Devleti kitabıyla Theodor Herzl atmıştır. Siyonizme açıkça ifade edilmiş siyasal bir hedef sağlayan Herzl'in çabalarıyla 1897'de Basel'de toplanan ilk Siyonist Kongresi'nde, Filistin'de Yahudi halkı için hukuken tanınan bir yurt sağlama hedefi benimsenmiş ve Dünya Siyonist Örgütü'nün kurulmasına karar verilmiştir. Ancak, Herzl, 1904'te ölene kadar Basel Programına devlet desteği bulamamıştır (Cleveland, 2015: 269). İngiltere'nin Filistin'e ilişkin stratejik çıkarları Siyonistlere bu devlet desteğini sağlayacak, 1917'de Balfour Deklarasyonu'nun ilanına giden yolu açacaktır.

Nisan 1920'de yapılan San Remo Konferansı'yla Suriye ve Lübnan Fransa, Filistin ve Irak İngiltere mandalarına verilmiştir. Filistin'de uluslararası yönetim yerine, İngiltere mandasının kurulmasında şüphesiz Balfour Deklarasyonu'yla Yahudilere milli yurt vaat edilmiş olması rol oynamıştır. İngiltere, Suriye'den koparılan Filistin'de Balfour Deklarasyonu'nun hükümlerini uygulamayı da taahhüt etmektedir. Yapay sınırlarla bölünen Arap devletleri İngiltere ve Fransa hakimiyetine girmekte, Arap bağımsızlığı sağlanamazken Yahudi milli yurdunun temelleri atılmaktadır. Bu bakımdan, 1920 yılının Araplar için 1948 Arap-İsrail Savaşı'ndan önceki ilk "Büyük Felaket” (El Nakba) olduğunu söylemek yanlış olmayacaktır (Kimmerling ve Migdal, 2003: 84).

\section{3. İNGILIZ MANDASI DÖNEMINDE ARAP-YAHUDİ ÇATIŞMASI}

Kendilerini Büyük Suriye'nin parçası olarak gören Filistinliler, San Remo Konferansı "Suriye Arap devleti içinde Filistin" düşüncesini ortadan kaldırınca, yeni stratejileri çerçevesinde Filistin'e ve Siyonizmin teşkil ettiği tehdide odaklanarak, 1948'e kadar bağımsız Filistin devleti düşüncesine bağlı kalmışlardır (Kimmerling ve Migdal, 2003: 84-86). Filistin mandasının İngiltere'ye bırakılması, Filistinlilerin Balfour Deklarasyonu'ndan kaynaklanan endişelerini yoğunlaştırmıştı. Deklarasyonda "Yahudi halkına" atıfta bulunulurken, nüfusun büyük çoğunluğunu oluşturan Filistinlilere ismen yer verilmemesi, Yahudilerin milli yurt haklarına karşılık, Yahudi olmayan toplulukların sadece medeni ve dini haklarından bahsedilmesi dikkati çekmekteydi. Manda rejiminin dayandığı anayasal çerçeve, Balfour Deklarasyonu'nu esas almakta ve Filistinli çoğunluğun ulusal ve siyasi haklarını görmezden gelmekteydi (Khalidi, 2006: 32-33). Oysa 1922'de Filistinliler 700 bin, Yahudiler 93 bin civarında bir nüfusa sahipti (Cleveland, 2015: 282). Bu anayasal yapı karşısında Filistinliler ne zaman ulusal ve siyasal haklarını talep etseler, kendilerine anayasal pozisyonlarının değişebilmesi için ön koşul olarak manda anayasasını kabul etmek zorunda oldukları ifade ediliyordu. Kabul etmeleri istenen anayasa ise Filistinlilerin haklarını inkar etmekte, onlara Yahudilerin altında bir statü tanımaktaydı (Khalidi, 2006: 32-33).

Filistinliler manda anayasasını ve Balfour Deklarasyonu'nu zımnen kabul etmeleri anlamına geleceği için, İngiltere'nin Yahudi-Arap işbirliği temelinde oluşturmayı planladığı siyasi-idari organlara katılmayı da reddetmişlerdir. Bu çerçevede, Filistin'deki mücadelenin, Yahudilerin Balfour Deklarasyonu'nu hayata geçirme ve bir devlet kurma çabaları, Filistinli Arapların da Deklarasyonu etkisiz kılma, Yahudilerin devlet kurmalarına izin vermeme ve bağımsız Arap devletini kurma çabaları etrafında geliştiği ifade edilebilir (Armaoğlu: 38).

Filistin'deki gerilim, Yahudi göçleri ve Yahudilerin toprak alımları nedeniyle giderek tırmanmış ve Filistinlilerin tepkisi daha 1920'lerden başlayarak kendisini göstermişse de, İngilizler ancak 1929'daki Ağlama Duvarı hadiselerinden sonra olayların nedenlerini araştırmaya yönelmişlerdir. 1929'da kurulan Shaw Komisyonu, gerilimin topraksız bir Arap sınıfı yaratılmasından ve Filistinlilerin, Yahudi göçlerinin Yahudi hakimiyetinde bir Filistin'e yol açması endişesinden kaynaklandığı tespitini yapmış, Yahudi göçü üzerindeki kontrolün arttırılmasını tavsiye etmiştir (Cleveland, 2015: 284-285). Daha ileri bir adım atarak, Yahudi göçünün engellenmesini ve Yahudilere toprak satışının sınırlandırılmasını tavsiye eden 1930 
Passfield Beyaz Kağıdı, Dünya Siyonist Örgütü'nün büyük tepkisini çekmiş, İngiltere belgenin geri alındığını açıklamak zorunda kalmıştır (Yılmaz Şahin, 2016: 47).

1933'te Almanya'da Nazilerin iktidara gelmesi, Yahudilerin Filistin'e göçlerini hızlandırmış, 1933-1936 arasında 170 bin civarında Yahudi'nin Filistin'e göç etmesi, Filistinlilerin endişelerini arttırmış, radikal eğilimleri güçlendirmiş, bütün Filistin'e yayılan bir şiddet dalgasına, toplumlar arası çatışmalara yol açmıştır. 1936' da Yahudilerin nüfusu 382 bine ulaşmıştı ve nüfustaki yükseliş toprak alımlarını da arttırarak, Filistinli köylülerin yoksullaşması sürecini hızlandırmaktaydı (Cleveland, 2015: 282-283).

1936'daki olaylar, İngiltere'nin yeniden bir komisyon görevlendirmesine neden olmuştur. Peel Komisyonu, Temmuz 1937'deki raporunda, Balfour Deklarasyonu'nun çelişkili yükümlülüklerinden üniter bir devlet yaratılamayacağı tespitini yapıyor, Filistin'in Arap ve Yahudi devletleri olarak taksimini öneriyordu, Arap devleti Şerif Hüseyin'in büyük oğlu Emir Abdullah'ın yönetimi altında Mavera-i Ürdün ile birleşecekti (Sayigh, 1997: 7). Bu öneri, İngiltere'nin Filistin ayaklanmasının lideri Hacı Emin El Hüseyni başkanlığında bağımsız Filistin devleti yerine, Abdullah'a bağl1 bir Filistin devletini tercih ettiğini göstermekteydi. Bu tercih, Abdullah ile Hüseyni arasında var olan düşmanlığ Filistin'in Arap nüfusu üzerinde etkili olma mücadelelerini arttırmıştır (Elpeleg, 1993: 51). Abdullah, bağımsız Filistin düşüncesine karşı çıkmış ve bu fikri savunan Hüseyni’ye karşı rakiplerini desteklemiştir.

Peel Komisyonu Raporu açıklanınca Filistin'de şiddet eylemleri yeniden başlamış, bir İngiliz yetkilinin öldürülmesi üzerine, 1936'da tüm rakip Filistinli grupların katılımıyla kurulan ve ayaklanmanın liderliğini yürüten Hüseyni başkanlığındaki Arap Yüksek Komitesi (AYK) dağıtılmış, liderleri tutuklanmış ya da sürgüne gönderilmiştir. Hüseyni, Fransa kontrolündeki Suriye'ye kaçmış ve isyanı buradan yönetmeye çalışmıştır. 1938'de yeniden şiddetlenen çatışmalarda çok sayıda Filistinli ve Yahudi ölmüş, isyancılar kırsal kesimin büyük kısmı ile bazı büyük şehirleri ele geçirmişlerdir. İngilizler ancak Mart 1939'da ve büyük bir askeri güç kullanarak ayaklanmayı bastırabilmiştir (Cleveland, 2015: 288). Ayaklanmada beş bin civarında Filistinli ölmüş, 10 bini yaralanmış, beş binden fazlası tutuklanmıştı. Kayıpların önemli bir kısmını deneyimli askeri kadrolar oluşturuyordu ve İngilizler ayaklanma sırasında büyük miktarda silah ve mühimmata el koymuştu. Bu ağır askeri kayıplar, İngiltere Filistin sorununu BM'ye götürdüğü ve Filistinliler ile Yahudiler arasında ülkeyi kontrol mücadelesi başladığında etkisini gösterecekti (Khalidi, 2001: 27).

Filistin ayaklanmasının yanı sıra, yaklaşan İkinci Dünya Savaşı öncesinde petrol kaynakları nedeniyle Ortadoğu'nun artan önemi ve Arap ülkelerinin Almanya'nın yanında yer almalarını önleme çabası, İngiltere'yi Filistin meselesini yeniden ele almaya zorlamış ve Mayıs 1939'da MacDonald Beyaz Kitabı yayınlanmıştır. Bu belgeyle; Filistin'in bir Yahudi devleti olmasının İngiltere'nin politikaları arasında yer almadığı belirtiliyor, Yahudi göçünün beş yıl boyunca 75 binle kısitlanması, bu süre sonunda Filistinliler devamını istemezse tamamen kesilmesi, Yahudilere toprak satışının belirli bölgelerle sınırlandırılması ve Filistin'e 10 yıl sonra bağımsızlık verilmesi öngörülüyordu (Cleveland, 2015: 288). Manda döneminde yayınladığı raporlar, İngiltere'nin, Filistinliler ile Yahudilerin uzlaşmaz talepleri arasında paralize olduğunu, Filistin ayaklanmaları ve Siyonizme desteği arasında, baskının doğduğu kaynağa bağlı olarak farklı çözümler üretip, sonra geri çekildiğini göstermekteydi (Khalaf, 1991: 65).

Nazi Almanyası'ndan kitlesel kaçışların sürdüğü bir dönemde yayınlanan MacDonald Beyaz Kitabı, Siyonistlerin İngiliz manda yönetimine karşı silahlı mücadele kararı almalarında büyük rol oynamıştır. Beyaz Kitap, AYK tarafından da reddedilmiş, Hüseyni radikal grupların etkisi ve bağımsızlığın 10 yıllık geçiş süresine bağlanması nedeniyle belgeyi kabul etmemiştir. 
Arap Ligi ise 1944'deki kuruluş toplantısı sonunda yayınlanan İskenderiye Protokolüyle 1939 Beyaz Kitabı'nda yer alan taahhütleri Arapların kazanılmış hakları olarak kabul edecektir (Armaoğlu: 69).

Filistinlilerin siyasi faaliyetlerinin kısıtlanması ve liderlerinin sürgünden dönmesine izin verilmemesi nedeniyle artan zayıflık ve bölünmüşlükleri savaştan sonra da devam etmiş, yeniden örgütlenme ve AYK'yı canlandırma girişimleri başarısızlığa uğramış,bu durum, kendilerini harekete geçirecek liderlikten yoksun kalmalarına neden olmuştur. Bu yüzden Filistin'i kurtarma ve İsrail devletinin doğuşunu önleme görevini Arap devletleri üstlenmiştir (Kumaraswamy, 2009: Ix-Ixi). Arap Ligi, Haziran 1946'da bir Filistin Komitesi ile Filistin Fonu ve Hüseyni başkanlığında Filistin İçin İcra Komitesi oluşturulmasına karar vermiştir. Arap Ligi ile ortak hareket ettiği görüntüsüne karşın Abdullah, taksimi halinde Filistin'in Arap kısmını Ürdün'e katma niyetini sürdürmüştür. (Armaoğlu: 70-71).1921'de İngiltere tarafından Mavera-i Ürdün yönetimine getirilen Abdullah, büyük Haşimi imparatorluğu ve halifeliği düşüncesine inanmış, yaşamı boyunca politik mevcudiyet ve etkisini Mavera-i Ürdün/Ürdün sınırları ötesine taşımaya çalışmış, Büyük Suriye idealinden hiçbir zaman vazgeçmemişti. Abdullah, Filistin ve Mavera-i Ürdün'ü kapsayan, Arapların ve Yahudilerin eşit olarak yaşayacakları, kendisinin yönetiminde bir 'Semitik Krallık' kurmayı amaçlamaktaydı (Shlaim, 2007). Abdullah'ın bu tutumu, BM'de taksim kararının alınması sonrasında Filistin sorunu bakımından büyük önem arz edecektir. Zira Abdullah Filistin'in taksimi kararından önce Yahudi Ajansı ile gizli görüşmeler yapmış, Yahudi Ajansı Abdullah'ın BM tarafından Yahudi devletine bırakılan alana girmeme sözüne karşılık, Arap devleti olarak işaretlenen alanın çoğunun Ürdün tarafından ilhakını kabul etmişti (Shlaim, 2007).

\section{4. İSRAIIL'İN KURULMASI VE ARAP-İSRAIIL ÇATIŞMASI}

İkinci Dünya Savaşı'nın sonunda Yahudi soykırımının boyutlarının öğrenilmesi, yarattığı şokun yanı sıra, uluslararası toplumda Yahudi davasına karşı büyük bir sempati doğurmuştur. Yahudi devletinin kurulması yalnızca haklı bir dava olarak değil, aynı zamanda Avrupa' daki Yahudi mülteciler sorununa da kısmi bir çözüm olarak görülmüştür (Best ve diğ., 2012: 134). Mültecilerin Filistin'e yerleştirilmeleri için Yahudi göçüne koyduğu sınırlamaları kaldırması konusunda özellikle ABD’nin yoğun baskısıyla karşılaşan İngiltere, bir yandan da Yahudilerin Filistin manda yönetimine yönelik şiddet eylemlerine maruz kalmıştır. Savaş sırasında Avrupa'dan akan göç dalgalarını ve illegal yollardan gelen göçmenleri engellemek için katı tedbirler alan İngiltere'nin tutumu, Siyonistlerin İngiltere'ye yönelik tepkilerini ve Yahudi devletinin güç kullanılarak kurulması kararlılıklarını güçlendirmiştir. Diğer yandan Siyonistler, değişen uluslararası güç dengesinde öne çıkan ABD'nin siyasi desteğini kazanmanın önemini de anlamışlardı. 1939 Beyaz Kitabı'nın kesinlikle reddedildiği, Filistin'e serbest göç ve Yahudi çoğunluğuna dayalı bir Yahudi devleti kurulması kararlarının alındığı 1942 Biltmore Konferansı'ndan (Yılmaz Şahin, 2016: 52) sonra ABD, uluslararası Siyonist faaliyetlerin merkezi olmuştu. 1945'te başkanlığa gelen Harry Truman, Siyonist lobinin artan etkisiyle 1948'e kadar Biltmore Programı'nı savunmuştur (Cleveland, 2015: 289-290).

ABD ve İngiltere'nin 1945 'ten itibaren, sadece mülteciler meselesini değil, genel olarak Filistin meselesini ele almak üzere birlikte ve ayrı ayrı yaptıkları çalışmalardan sonuç alınamayınca İngiltere Filistin sorununu BM’ye götürmeye karar vermiştir. BM Filistin Özel Komitesi'nin Filistin'in taksimini ve Arap ve Yahudi devletlerinin kurulmasını öngören Çoğunluk Planı'nın 29 Kasım 1947'de kabulüyle Filistin sorunu kritik bir dönemece girmiştir. Kararın kabulünde ABD ve Sovyetler Birliği'nin tutumu belirleyici olmuş, İngiltere'nin en kısa sürede bölgeden çekilmesini ve meydana gelecek boşluktan yararlanarak Ortadoğu'ya girmeyi planlayan Sovyetler Birliği, Arap ülkelerinin beklentilerini boşa çıkararak kararı kabul etmiştir (Armaoğlu: 89). ABD askeri ve dışişleri yetkililerinin aksi yöndeki tavsiyelerine karşın, Yahudi 
lobisinin etkisi altındaki Başkan Truman da taksimden yana tavır almıştır (Khouri, 1985: 51). Siyonistler başlangıçta karşı çıktıkları Çoğunluk Planı'nı sonradan kabul etmiş, daha BM'deki görüşmeler sırasında taksim kararına şiddetle direneceklerini belirten Arap ülkeleri, kararın ardından askeri hazırlıklara başlamışlardır.

Taksim kararının alındığı Kasım 1947'den İngiltere'nin Filistin'den çekildiği 14 Mayıs 1948'e kadar olan dönemde Filistin'de toplumlar arası çatışmalar şiddetlenmiş, Yahudi güçlerinin, BM kararıyla Yahudilere ayrılan toprakları kontrol altına almak amacıyla düzenledikleri saldırılar karşısında dağınık Filistin güçlerinin karşı koyma çabaları sonuçsuz kalmış, belli başlı Arap merkezleri Yahudilerin eline geçmiş, 400 bin civarında Filistinli kaçmak zorunda kalmıştır. Siyonistlerin üstün ve disiplinli güçlerine karşılık Filistin liderliğindeki bölünmüşlük, Filistin politik kurumlarının zayıflığı, eğitimli ve düzenli Filistin güçlerinin eksikliği, merkezi komuta yapısının yokluğu ve güvenilir silah kaynaklarının olmaması, Filistin toplumunun çöküşüne yol açan başlıca faktörler olmuştur (Khalidi, 2001: 13-15). Filistinliler bu ağır travmadan sonra uzun süre toparlanamayacak, Filistin mücadelesi Filistinli olmayan Arapların liderliğinde şekillenecektir. Arap devletlerinin Filistin'in kurtarılması amacıyla Mayıs 1948'de İsrail'e savaş açmasıyla Filistin sorunu Arap-İsrail sorununa dönüşecektir.

\subsection{Arap-İsrail Savaşı}

15 Mayıs 1948'de Ürdün, Irak, Suriye, Mısır ve Lübnan ordularının Filistin'e girmesiyle başlayıp, 7 Ocak 1949'da biten 1948 Arap-İsrail Savaşı'nın ilk günlerinde Araplar, nispi bir üstünlük elde etmiş, Mısır Gazze'yi, Ürdün Kudüs'ün doğu kesimi dahil, Batı Şeria'yı almıştır. Ancak ateşkes sırasında, ambargoya rağmen, Sovyetler Birliği’nin Çekoslovakya kanalıyla silah sağlaması(Armaoğlu: 95) ve insan ve ateş gücünü takviye etmesi sayesinde İsrail toparlanarak, üstünlüğü ele geçirmiştir. Arapların savaşı kazanamayacağı anlaşılınca 1949'da yapılan ateşkes anlaşmalarıyla nihai olmayan ateşkes sınırları belirlenmiştir. Buna göre, Filistin; İsrail, Mısır, (Gazze Şeridi) ve Ürdün (Doğu Kudüs ile Batı Şeria) arasında paylaşılmıştır (Cleveland, 2015: 297). İsrail, “bütünlüklü ve savunması mümkün bir sınır” elde etmiş, Filistin, Taksim Planı'na göre elinde olması öngörülen toprakların büyük kısmını kaybetmiş, Kudüs bölünmüş, yaklaşı 150 bin Filistinli İsrail, 450 bin Filistinli Ürdün, 200 bin Filistinli de Mısır yönetiminde kalmış, 750-800 bin civarında Filistinli mülteci durumuna düşmüştür (Best ve diğ., 2012: 144).

İsrail, 1948 Arap-İsrail Savaşı'nda Filistinlilerin savaşın bir sonucu olarak topraklarını kendilerinin terk ettiğini, İsrail'in bundan sorumlu olmadığını ileri sürmektedir. İsrail, 19481951 yılları arasında ülkesine gelen 600 bin civarında Yahudi göçmeni, boş Filistin köylerine, kentlerdeki boş binalara, çiftlik arazilerine yerleştirmiştir (Cleveland, 2015: 394-395). Yani, Filistinlilerin dönecekleri bir evleri, işleyecekleri bir toprakları kalmamıştır. BM Genel Kurulu'nun 194 sayılı kararı, geri dönüşlerini kendi isteklerine bırakarak, Filistinlilerin İsrail'den kendi iradeleri ile ayrıldıkları fikrini üstü kapalı bir şekilde kabul etmekte, "komşuları ile barış içinde yaşamak isteyen" mültecilerin dönüşlerinin sağlanması gibi bir ifadeyle de adeta Filistinlilerin, “komşuları ile barış içinde yaşamak istemedikleri için” İsrail'i terk ettiklerini ima etmektedir.

Filistinli mülteciler, Lübnan, Ürdün, Suriye, Mısır, Gazze Şeridi ve Batı Şeria'daki mülteci kamplarıyla, durumları daha iyi olanların gidebildikleri diğer Arap ülkeleri, Avrupa ve Kuzey Amerika'ya dağılmış, geniş bir diaspora oluşturmuşlardır. Mülteci kamplarında yaşayan Filistinliler, Ürdün dışında vatandaşlık hakları kazanmamış, sınırlı çalışma imkanlarına, kısıtlı hareket özgürlüğüne sahip olmuş, siyasal faaliyetleri de kuşkuyla karşılanmıştır. Kamplarda tutulmaları ve yaşadıkları toplumlarla bütünleşmemeleri, mültecilerin Filistinli kimliklerini korumaları sonucunu doğurmuştur. Bununla birlikte, 1967 Arap-İsrail savaşının ağır 
sonuçlarının yarattığı bağımsız çizgide bir siyasi liderliğe sahip oluncaya kadar, kaderlerini Arap ülkelerine bağlamışlardır.

1967'deki ikinci Arap-İsrail Savaşı'na kadar olan dönem, İsrail'den intikam alma duygularının güçlü olduğu, Nasırcılığın Arap milliyetçiliğine yeni bir ruh ve güç katıp, tüm bölgede etkisini sürdürdüğü ve 1955 tarihli Bağdat Paktı'nın yol açtığı Batı aleyhtarı tepkiden yararlanan Sovyetler Birliği'nin Arap ülkeleri üzerinde etkisinin artmaya başladığı bir dönem olmuştur. 1957'de bölge ülkelerine ekonomik yardımın yanısıra, komünizm tehdidine karşıaskeri yardımda bulunmayı öngören Eisenhower Doktrini’yle, Soğuk Savaş'ın yarattığı bloklaşma Ortadoğu'yu da etkisi altına almıştır. Arap-İsrail sorunu söz konusu olduğunda, bu kamplaşma, ABD-İsrail/SSCB-Arap ülkeleri şeklinde kendisini göstermiştir. Sovyetler Birliği'nin ilk Arap-İsrail savaşında İsrail'i desteklerken, ikincisinde Arapları desteklemesi, bölgeye yerleşmek için gerilim yaratma ve bunu istismar etme anlayışını bir kez daha ortaya koymuştur.

1948 Savaş1,Filistin meselesine ilişkin olarak Arap ülkeleri arasında ciddi bir mücadeleye yol açmıştır. Batı Şeria ve Gazze Şeridi'ni kontrol altında tutmaları nedeniyle soruna doğrudan müdahil olan Ürdün ve Misır'ın iki tarafında yer aldığı bu mücadele, Filistinlilerin temsil edilmesi ve Filistin siyasi oluşumu (entitesi) meselesi etrafinda yürütülmüştür

\subsection{Filistin Sorunu Konusunda Ürdün ile Mısır Arasındaki Mücadele}

1948 savaşı devam ederken, Eylül 1948'de Hüseyni başkanlığındaki AYK, bütün Filistin topraklarını içine almak üzere Gazze'de bir Filistin hükümeti (All-Palestine Government) kurulduğunu ilan etmiş ve cumhurbaşkanlığına Hüseyni’yi getirmiştir. Bu hükümetin kurulmasındaki ana amaç, Ürdün Kralı Abdullah'ın Filistin topraklarını ilhak niyetini önlemekti. Arap Ligi ve özellikle Misır tarafından desteklenen hükümet, Ürdün dışındaki Arap ülkelerince tanınmasına karşın, yöneteceği bir halkı, toprağı, ordusu, bütçesi olmadığı için kağıt üstünde kalmıştır (Shemesh, 1996: xiii). Mısır Kralı Faruk'un Gazze üzerinden ve Hüseyni vasitasıyla yaptığı bu hamleye Abdullah, Aralık 1948'de, Eriha Kongresi'nde Filistin topraklarının Ürdün ile birleştirilmesi ve Abdullah'ın 'Bütün Filistin'in Kralı” ilan edilmesiyle karşılık vermiştir. Ürdün parlamentosu da Nisan 1950'de Batı Şeria ve Doğu Kudüs'ün Ürdün'e ilhakını onaylayacaktır (Armaoğlu: 102). Ürdün'ün Batı Şeria'yı ilhak kararı Filistin'in bağımsızlığı düşüncesini ortadan kaldırmış, Gazze'deki Filistin hükümetinin çöküşünde de en kritik unsur olmuştur. Taksim Planı'nda Filistin'e bırakılan toprakların çoğunu işgalleri altında tutan Arap ülkelerinin bu topraklarda bir Filistin devleti kurmayı başaramamaları -en azından 1967'ye kadar- Filistin devletinin kurulamamasından İsrail ölçüsünde sorumlu olduklarını göstermekte ve Filistin davasını zayıflatmaktaydı (Kumaraswamy, 2009: Ixi).

Ürdün 1954 'de vatandaşlık hakk1 vereceği Filistinlilerin parlamentoda temsiline de imkan tanımıştı. Filistinliler büyük Ürdün toplumunun bir parçası olarak kabul edilmekte, ayrı bir Filistin kimliğine vurgu yapılmamaktaydı (Köprülü, 2009: 200). İlhak kararı, Ürdün'ün demografik yapısında önemli bir değişikliğe yol açmış, Filistinliler nüfusun üçte ikisini meydana getirirken, Doğu Şerialılar olarak adlandırılan yerli Ürdünlüler azınlık durumuna düşmüştür. Bu demografik yapı, Ürdün'ün Filistinlileri temsil ettiği iddiasına dayanak oluşturacağı gibi, rejimini tehdit eden bir nitelik de kazanacaktır.

Ürdün'ün Filistinlileri asimile etmeyi amaçlamasına karşılık Mısır, Gazze Şeridi ile Mısır'ı ayrı tutmuş, Gazze Şeridi'nin Filistin'in bağımsızlığına kadar Mısır'ın "emanetinde” olduğunu ve gerçek sahiplerine döneceğini savunmuş, Ürdün bakımından da Batı Şeria'nın aynı durumda olması gerektiğini, ancak Ürdün'ün Batı Şeria'yı ilhak ederek Filistin'in varlığını/bağımsızlığını ortadan kaldırdığı görüşünü ileri sürmüştür (Shemesh, 1982: 8). 
1952'de Nasır liderliğindeki Hür Subaylar Hareketi'nin Mısır'da iktidarı ele geçirmesinden sonra başlatılan Filistin fedai eylemlerinin kısa ömürlü olması, Mısır'1 yeniden bir Filistin hareketi başlatmaya sevk etmiş, bu çerçevede 1959'da Filistin siyasi oluşumu meselesi Arap Ligi'nin gündemine getirilmiştir (Armaoğlu: 220-222).

Nasır'a göre İsrail, Arap-İsrail çatışmasının İsrail ile Filistinliler arasında değil, İsrail ile Arap devletleri arasında olduğunu kanıtlamayı ve böylece Filistin meselesini bitirmeyi amaçlamaktaydı. Bu yüzden Mısır, Filistin unsurunun varlığını kanıtlayacak Filistin temsili kurumlarının oluşturulmasını gerekli görüyor, Filistin faktörünün İsrail'e karşı Arap mücadelesini meşrulaştıracağını düşünüyordu (Shemesh, 1982: 4).

Filistin halkını temsil edecek bağımsız siyasi kurumlar oluşturulması ve Filistinlilerin seçilmiş temsilcileri kanalıyla uluslararası platformlarda temsil edilmeleri amaciyla gündeme getirilen öneri, nihai olarak Filistin topraklarında bir siyasi oluşum/devlet kurulmasını hedeflemekteydi. Filistin siyasi oluşumunun esas itibarıyla Batı Şeria'da kurulacak olması, bu topraklardaki egemenliğinin sona ermesi anlamına geleceği için Ürdün plandan rahatsızlık duymuştu. Ürdün sadece Batı Şeria'yı kaybetmekle kalmayacak, aynı zamanda burada oluşacak siyasi oluşumun, Filistin halkının seçilmiş temsilcisi olarak Doğu Şeria'daki Filistinlileri temsil ettiği iddiasıyla karşılaşacaktı. Mısır, Batı Şeria'da bir Filistin devleti kurulmasının Haşimi Krallığı'nın küçülmesi, hatta sona ermesi anlamına geldiğinin farkındaydı. Nasır'ın uzun vadedeki amacı, muhtemelen yalnızca Ürdün rejiminin düşmesi değil, fakat Ürdün'ün yerini alacak bir Filistin devletinin kurulmasıydı (Shemesh, 1982: 7-8).

Ürdün Kralı Hüseyin, Mısır'ın planının Ürdün'ün bütünlüğü ve istikrarı için oluşturduğu tehdidi dikkate alarak plana tüm yönleriyle karşı çıkmıştır. Bu çerçevede Ürdün, öncelikle temsil meselesi ile ilgili olarak Ürdün hükümetinin Ürdün'de yaşayan Filistinlilerin tek yasal temsilcisi olduğunu, Ürdün vatandaşları adına konuştuğunu ve Filistinlilerin büyük bir çoğunluğunu temsil ettiğini savunuyordu. Ürdün'ün ikinci argümanı, Batı Şeria'nın ilhakının, Batı Şeria sakinlerinin Ürdün'le birleşme iradesinin sonucu olduğu ve Filistin sorununun çözümüne yönelik bir planın Ürdün'ün mevcut statüsünü tanımak zorunda olduğuydu (Shemesh, 1982: 24-25). Ürdün'ün diğer bir tezi, Filistin siyasi oluşumu probleminin yalnızca kapsamlı bir Arap planı çerçevesinde tartışılması gerekliliğiydi. Mısır'ın aksine Ürdün, Arap-İsrail çatışmasının Filistin halkı ile İsrail arasında değil, Arap dünyası ile İsrail arasında olduğunu ve bu soruna çözüm bulma sorumluluğunun tüm Araplara ait olduğunu ileri sürüyordu. Ürdün bu şekilde, Filistinlilere sorumluluk vererek temsili Filistin kurumlarına yol açacak Mısır planını bertaraf etmeyi amaçlamaktaydı. (Shemesh, 1982: 25).

Ancak Ürdün, 1959-1963 arasındaki Filistin siyasi oluşumu planlarına karş1 mücadelesinde başarılı olamamıştır. Nitekim Arap Ligi, Eylül 1963 'te Kahire'de yaptığ toplantıda bir Filistin siyasi oluşumu teşkiline, Filistinlilerin sürgünde hükümet kurmalarına ve bir ulusal konsey seçmelerine ve Filistin Kurtuluş Ordusu'nun oluşturulmasına karar vermiştir (Armaoğlu: 222). Bunun ardından Mayıs 1964'te Doğu Kudüs'te toplanan ilk Filistin Ulusal Konseyi (FUK)'nde Filistinli Arapların temsilcisi olarak FKÖ'nün kurulduğu açıklanmıştır. FKÖ, Filistin'in İngiliz mandası altındaki tarihi Filistin toprakları olduğunu kabul ederek İsrail'in varlığını reddediyor, BM'nin taksim kararı ile Balfour Deklarasyonu'nun geçersiz olduğunu ilan ediyor, Filistin'in kurtarılmasının meşru savunma hareketi olduğunu açıklıyordu (Armaoğlu: 223).FKÖ, başlangıçta Nasır'ın politikaları doğrultusunda bir çizgi izleyecek, 1967 Arap-İsrail Savaşı sonrasındaki gelişmeler ve Filistin mücadelesinde El Fetih'in ön plana çıkmasıyla 1969'dan itibaren farklı bir yaklaşım benimseyecektir.

\subsection{Arap-İsrail Savaşı}

Haziran 1967'deki Altı Gün Savaşı olarak da bilinen Arap-İsrail Savaşı, 1966'da Suriye'de Baas Partisi'nin iktidara gelmesinden sonra artan Suriye-İsrail gerginliği, Suriye ile 
Mısır arasında karşılıklı savunma anlaşması imzalanması, Suriye ve Ürdün'den İsrail'e yönelik olarak sürdürülen Filistin gerilla faaliyetleri nedeniyle, İsrail'in kendisini kuzeyden ve güneyden iki düşman devlet arasında sıkışmış hissetmesi ve önleyici amaçlı bir harekat planlamasıyla gündeme gelmiştir. Mısır'ın, Ruslardan gelen, İsrail'in Suriye sınırına yığınak yaptığı istihbaratı üzerine, önce Sina' ya girip, buradaki BM gücünün çekilmesini sağlayarak, İsrail ile arasındaki tampon bölgeyi ortadan kaldırması ve ardından Tiran Boğazı'nı kapatması, İsrail tarafından savaş nedeni olarak kabul edilmiştir (Best ve diğ., 2012: 469-470). İsrail Hava Kuvvetleri'nin 5 Haziran 1967'de Arap havaalanlarına eş zamanlı saldırısıyla henüz havalanmamış, 304 Mısır, 53 Suriye ve 287 Ürdün uçağı vurulmuş, hava üstünlüğü 10 Haziran'a kadar süren kara savaşında İsrail'in, Mısır, Suriye ve Ürdün'ü rahatça yenmesine yol açmıştır. Bu şekilde, Gazze Şeridi, Batı Şeria ve Doğu Kudüs'ün, yani tüm Filistin topraklarının ve Suriye'nin Golan Tepeleri ile Mısır'ın Sina Yarımadası'nın kontrolünü ele geçiren İsrail, topraklarını üç katına çıkarmış, güvenliği için çok önem verdiği stratejik derinliği kazanmıştır (Best ve diğ., 2012: 471). Kudüs'ün tamamen İsrail hakimiyetine girmesi sadece Arap ülkelerinde değil, tüm Müslüman dünyasında büyük tepkiye yol açmıştır.

Savaş, Filistinli mülteciler meselesine yeni boyutlar katmış, İsrail ele geçirdiği topraklar ile birlikte 1,5 milyon civarında Filistinli nüfusla nasıl başa çıkacağı sorunuyla karşı karşıya kalmıştı. Toprakların elde tutulması, Filistinli sakinlerine İsrail yurttaşlığı verilmesini gerektirebileceğinden, demografik dengeyi İsrail aleyhine değiştirebilecek, devletin Yahudi karakterini bozabilecek bir durum olarak görülmekteydi. Sorun, askeri yönetim kurup, yetki ve sorumluluğu askeri idareye transfer etmek suretiyle aşılmıştır (Fahreddin ve Çalışkan, 2000).

Savaş sonunda kabul edilen 242 sayılı BM Güvenlik Konseyi kararı, İsrail'in 1967'de işgal ettiği topraklardan çekilmesini öngörmekte, bölgedeki her devletin "güvenlikli ve tanınmış sınırları" içinde yaşaması hakkını kabul etmekteydi. Mısır, Ürdün ve İsrail kararı tanımış, Suriye ise tanımamıştır. Ancak, Arap ülkeleri önce İsrail'in işgal ettiği topraklardan çekilmesini, İsrail ise önce müzakere masasında "güvenlikli ve tanınmış sınırların" tespit edilerek, çekilmenin buna göre yapılması gerektiğini savunmuştur (Armaoğlu, 1991: 709-710). $\mathrm{Bu}$ durum, barışçı ve taraflarca kabul edilmiş bir anlaşma yapılmasına uzun yıllar imkân vermemiştir. Kararın bir diğer unsuru da, Filistinli mülteciler sorununa adil çözüm getirilmesi çağrısıydı. FKÖ, Filistinlilerden devlet kurma hakkı olan bir halk olarak değil, sadece bir mülteci sorunu olarak söz edilmesi ve İsrail'in var olma hakkını tanıması nedeniyle 242 sayılı kararı kabul etmemiştir (Cleveland, 2015: 398).

1967 Arap-İsrail savaşının Filistin sorunu bakımından en önemli sonucu, Filistinlilerin kendi mücadelelerinin sorumluluğunu üstlenmeleri olmuştur.1947-1967 arasında Arap devletleri Filistinliler adına konuştuklarını ileri sürmüşler, Filistinlilerin siyasi sürece aktif katılımını desteklememişlerdir. 1967'deki topyekûn yenilgiyle bu iddialar sona ermiş ve o güne dek Araplar arası siyasetin aracı olan FKÖ, tamamen yeni bir rol elde etmiştir (Lewis, 2015: 458).

El Fetih Lideri Yaser Arafat'ın başına geçmesiyle FKÖ, Arap ülkelerinden olabildiğince bağımsız bir politika izlemeyi hedeflemiş, sonunda bir Filistin milli kimliği oluşturmayı başarmıştır. Milli kimliklerini keşfeden Filistinlilerin, Arap-İsrail çatışmasının aslında İsrail ile Filistin arasındaki bir sorun olduğu konusunda uluslararası toplumu bilinçlendirmesiyle (Cleveland, 406), Filistin yeniden merkezi konumuna dönecektir. Arap-İsrail çatışması ise Arap devletlerinin artık kendi topraklarını kurtarmaya öncelik verdiği 1973 Arap-İsrail Savaşı'yla devam edecektir.

\subsection{Arap-İsrail Savaşı}

Nasır'in 1971'deki ölümünden sonra yerine gelen yardımcısı Enver Sedat, İsrail'in Sina'dan çekilmesini ve Süveyş Kanalı'nın yeniden uluslararası deniz trafiğine açılmasını 
sağlamak ve bozulan ekonomiyi düzeltmek için, hem savunma harcamalarının yükünden kurtulup, hem Amerikan yardımı alabilmek düşüncesiyle, İsrail ile barış yapılmasını planlamış, ancak, o günkü sınırlarını güvenliği için hayati önemde gören İsrail bu öneriyi kabul etmemişti (Best ve diğ., 2012: 474). Bunun üzerine Sedat, İsrail Ordusu'nun sanıldığı kadar güçlü olmadığını göstererek ABD'nin devreye girmesini sağlamak amacıyla savaşı bir diplomasi aracı olarak kullanmaya karar vermiştir (Cleveland, 417). Bu çerçevede, Mısır, Suriye ve Ürdün arasında yapılan savaş planlamalarının ardından, İsrail'in Yom Kippur tatilinde olduğu 6 Ekim 1973 'te Mısır ve Suriye kuvvetleri iki ayrı cepheden İsrail'e saldırıya geçmişlerdir (Armaoğlu, 1991: 718-719). Mısır Ordusu Süveyş Kanalını geçmeyi, Suriye Ordusu da Golan’ı işgal etmeyi başarmıştır. Ancak İsrail'in, ABD'nin havadan cephane ikmali yaparak yardımda bulunduğu karşı saldırısı üzerine durum değişmiş ve ateşkes ilan edilmiştir. 1974'de, ABD Dışişleri Bakanı Henry Kissinger'in "mekik diplomasisi” sonucunda, İsrail ile Misır ve Suriye arasında ayırma anlaşmalarının imzalanması önemli bir gelişme olmuştur. Bu anlaşmalar, İsrail'in işgal ettiği topraklardan -Sina ve kısmi olarak Golan- çekilebileceğini göstermiş ve FKÖ'nün politikasında bazı değişikliklere yol açmıştır. İsrail ile Ürdün arasında bir ayırma anlaşması yapılması halinde, 1967'de Ürdün'den alınan Batı Şeria'nın bu ülkeye iade edilme olasılığı ve ABD'nin FKÖ’yü devre dışı bırakıp Ürdün ile anlaşmayı tercih edeceğinin anlaşılması, Arap ülkelerini ve FKÖ’yü harekete geçirmiştir.

FKÖ, Haziran 1974'te 10 maddelik bir siyasi program kabul ederek Filistin topraklarının İsrail'den kurtarılan herhangi bir parçasında bağımsız ulusal otorite kuracağını açıklamıştır. Bu değişiklik, FKÖ’nün Batı Şeria ve Gazze'de bir Filistin devleti kurulmasını onayladığı ve zımnen de olsa İsrail'in varlığını tanıdığ 1 şeklinde yorumlanmıştır. Bununla birlikte, siyasi programda 242 sayılı BM kararı reddedilmekte ve İsrail'e karşı silahlı mücadelenin sürdürüleceği belirtilmektedir. Siyasi programın açıklanmasından sonra Ekim 1974'te Rabat'ta yapılan Arap Zirvesi'nde FKÖ'nün Filistin halkının tek meşru temsilcisi olarak tanınması, Ürdün'ün Filistinlileri temsil iddiasına ciddi bir darbe olmuştur. Bu nedenle Kral Hüseyin, kararı ancak Arap ülkelerinin yoğun baskıları ve maddi yardım taahhütleri karşılığında kabul etmiştir. Ancak gerçekte Ürdün, ABD ve İsrail'in terör örgütü olarak gördüğü FKÖ’ye yönelik tutumu nedeniyle, FKÖ'nün temsilcilik rolünü yerine getirebileceğine inanmamaktadır. Ayrıca Ürdün'e göre, Rabat Zirvesi kararı Filistin halkına danışılmadan alınmış ve FKÖ Filistin halkına empoze edilmiştir (Susser, 1994: 214-217).

1973 Arap-İsrail savaşının bir diğer sonucu, Arap ülkelerinin petrolü Batıya karşı silah olarak kullanmaya karar vermeleri ve bütün dünyada bir petrol krizinin ortaya çıkması olmuştur. Petrol üreticisi Arap ülkelerinin Suriye ve Mısır'ı desteklemek amacıyla, İsrail işgal ettiği Arap topraklarından çekilinceye kadar petrol üretimini kısacaklarını açıklamaları petrol fiyatlarını hızla yükseltmiştir. Petrol fiyatlarındaki artışlar, özellikle Batı Avrupa ve Japonya'da paniğe neden olmuş, ancak sarsıntı kısa sürede atlatılmıştır. Sonuçta, BM'nin 242 ve 1973 savaşı sonunda kabul edilen aynı içerikteki 338 sayılı kararlarının desteklendiğine dair yapılan bazı açıklamalar dışında, Batılıların ve ABD'nin Ortadoğu politikasında ciddi bir değişiklik meydana gelmemiştir.

1973 savaşı sonunda Mısır, yalnızca Sina’yı geri almakla kalmamış, ABD ile ilişkilerini geliştirerek, Sovyet kampından uzaklaşmaya başlamıştır. Mısır gibi önemli bir Arap ülkesinin ABD ile yakınlaşması, Ortadoğu'da dengeleri ciddi şekilde etkileyecektir. Esasen 1973 savaşının en önemli sonuçlarından biri 1978 Camp David anlaşmalarına giden yolu açmış olmasıdır.Camp David anlaşmalarıyla Mısır, İsrail ile ikili barışın sağlanmasından ziyade, kapsamlı bir Ortadoğu barışını ve Filistin sorununun çözümünü amaçlamaktaydı. Ancak, İsrail'in olumsuz tutumu buna imkan vermemiştir. 
İsrail-Mısır barışı, Arap dünyasında büyük bir tepkiyle karşılanmış, Arap ve Filistin davasına ihanet olarak görülmüş, Mısır'ın Arap Ligi'nden çıkarılmasına neden olmuştur. ABD, ilk kez bir Arap ülkesinin İsrail ile barış anlaşması imzalamasını ve en büyük Arap ordusunun savaştan çekilmesini sağlayarak, İsrail'in güvenliği için çok önemli bir adım atmıştır. Mısır'ın "Arap düşmanlık çemberinden" ayrılması, 1948 savaşı sonrasında İsrail devletini meşru kabul etmeme ve boykot politikası izleyen Arap stratejisindeki ilk büyük çatlaktır (Rabinovich ve Brun, 2017). Ancak, anlaşmanın diğer Arap ülkelerini de İsrail ile uzlaşmaya yönelteceği beklentisi gerçekleşmemiş, aksine Arapların İsrail'e yönelik tutumu sertleşmiştir.Bunun başlica nedenlerinden biri, aşırı sağcı görüşleriyle tanınan Menahem Begin başkanlığındaki Likud hükümetinin uyguladığı ilhak ve yerleşim politikalarıdır.

Likud hükümeti Camp David'den hemen sonra Ekim 1978'de Tel Aviv'deki bakanlıkları Kudüs'e nakletmeye başlamış, 1980'de Doğu Kudüs'ü ilhak ederek Kudüs'ü İsrail'in bölünmez ve ebedi başkenti ilan etmiş, 1981'de de Golan'1 ilhak etmiştir (Armaoğlu, 1991: 746-747). Öte yandan, işgal altındaki topraklarda, özellikle "Judea ve Samaria" olarak adlandırılan Batı Şeria'da Yahudilerin ebedi ve tarihi hakları olduğu belirtilerek yoğun bir yerleşim politikası uygulanmaya başlanmıştır.

Likud, FKÖ’yü temsil gücünden yoksun bırakmak ve uluslararası alanda zayıflatmak amacıyla işgal altındaki topraklarda FKÖ karşıtı ya da en azından ondan bağımsız bir lider kadrosu yaratmayı hedeflemiştir. FKÖ’nün işgal altındaki topraklarda giderek artan etkisini de dikkate alan Likud Hükümeti, 1982'de Lübnan'a müdahale ederek, sadece FKÖ’nün bu ülkeden çıkarılmasını değil, aynı zamanda işgal altındaki topraklarda yükselen Filistin milliyetçiliğini de önlemeyi amaçlamıştır.

\section{5. İsrail'in Lübnan'ı İşgali}

1970-71'deki Ürdün iç savaşından sonra karargahını Lübnan'a taşımak zorunda kalan FKÖ'nün Lübnan'daki faaliyetleri, karmaşık sosyal-siyasal yapısı içindeki dengeleri etkileyerek Lübnan'ın istikrarsızlığını arttırmış, 1975-1976 iç savaşının çıkmasında önemli bir faktör olmuştur. FKÖ karargahı Beyrut'a taşınmadan önce de Lübnan, Filistinli gerillaların yoğun faaliyetine sahne olmakta ve Filistinli gerillaların Güney Lübnan'dan İsrail'e yönelik saldırıları 1969'dan itibaren Lübnanlı siyasetçiler arasında tartışma yaratmaktaydı. Lübnan yönetimindeki hakim grup olan Hıristiyanların İsrail'in misillemelerine maruz kalmamak için Filistinli gerillalara karşı Lübnan Ordusu'nu harekete geçirmeleri, Müslüman siyasetçilerin tepkisine neden olmuş, Hıristiyanlar ile Müslümanlar arasında Filistinlilerin de dahil olduğu 1975-76 iç savaşının çıkmasını tetiklemiştir. Bu savaşta İsrail, Hıristiyan grupları ağır silah ve İsrail'de askeri eğitim vermek suretiyle desteklemiştir (Armaoğlu, 523).

Suriye'nin 1976'daki askeri müdahalesiyle ülkenin kontrolünün Filistinli gerillaların eline geçmesi önlenmiş, Arap devletlerinin devreye girmesiyle bir Arap Caydırma Gücü'nün (bu gücün büyük kısmı Suriye askerlerinden meydana geliyordu ve Suriye'nin Lübnan'da bulunmasına da meşruiyet kazandırıyordu) kurulmasına karar verilmiş, ancak HiristiyanMüslüman çatışmaları ve Filistinlilerin İsrail'e saldırıları devam etmiştir. 1978'de El Fetih militanlarının deniz yoluyla Lübnan'dan Hayfa'ya gelip bir otobüsü ele geçirmeleri ve HayfaTel Aviv Karayolu'nda 34 İsrailli sivili öldürmeleri üzerine İsrail, Güney Lübnan'1 işgal etmiştir. $\mathrm{Bu}$ işgal uzun süreli olmamış, İsrail altı millik bir güvenlik kuşağı oluşturup, kontrolünü Maruni subay Saad Haddad liderliğindeki Hür Lübnan Ordusu'na birakarak çekilmiştir (Armaoğlu, 534-537). Ancak 1982'de İsrail'in Londra Büyükelçisi'ne yönelik suikast girişimi, İsrail'in bu kez Lübnan'1 tümüyle işgal etmesine neden olmuştur. İsrail bu işgalle sadece FKÖ'yü değil, Suriye'yi de Lübnan'dan çıkarmayı, işbirliği yaptığı Falanjist lider Beşir Cemayel'in Cumhurbaşkanlığına gelmesini ve Lübnan'da kendisine yakın bir yönetim tesis ederek Lübnan'ın İsrail ile barış yapmasını sağlamayı amaçlamaktaydı 
(Rabinovich ve Brun). Haziran 1982'de başlayan işgalin ilk günlerinde İsrail ile Suriye kuvvetleri arasında meydana gelen çatışmalarda 1000 civarında Suriyeli asker ölmüş, 300 kadar Suriye tankı ve 60'dan fazla Suriye savaş uçağı imha edilmiştir (Armaoğlu, 544). Öte yandan, FKÖ'nün Beyrut'taki karargahı deniz, hava ve karadan kuşatma altına alınmış, iki aya yakın süre bombalanmıştır. Bu durum sivillerin de zarar görmesi nedeniyle ABD'nin hoşnutsuzluğuna yol açış ve İsrail nezdindeki girişimleri sonunda Arafat'ın da kabul etmesiyle FKÖ'nün ağır silahlarını bırakarak Beyrut’tan ayrılması kararlaştırılmıştır. FKÖ’nün ABD, Fransa ve İtalya'nın oluşturduğu Çok Uluslu Güçgözetiminde Beyrut'tan ayrılmasından sonra Cumhurbaşkanı Beşir Cemayel'in öldürülmesi ve Falanjistlerin Sabra ve Şatilla Filistin mülteci kamplarındaki katliamlarının yarattığı tepkiler, İsrail'in diğer amaçlarını gerçekleştirmesine izin vermemiştir. İsrail'in, Lübnan'ın kendisine yönelik saldırılarda üs olarak kullanılmasını önleyecek garantileri elde etmeden Lübnan'dan çekilmeyeceğini açıklaması nedeniyle Mayıs 1983'te İsrail ile Lübnan arasında güneyde Lübnan Ordusu gözetiminde bir güvenlik bölgesi oluşturulmasını öngören bir anlaşma imzalanmış, bunun üzerine İsrail Güney Lübnan'a çekilmiştir. Ancak, Suriye'nin anlaşmayı tanımayacağını ve Lübnan'dan çekilmeyeceğini belirtmesi üzerine Lübnan hükümeti anlaşmayı feshetmiştir. Bu şekilde İsrail'in Güney Lübnan, Suriye'nin de Bekaa Vadisi ve Beyrut'taki fiili hakimiyetleri başlamıştır (Armaoğlu, 566-567).

FKÖ Lübnan'1 terke zorlandıktan sonra karargahını Tunus'a taşımış, İsrail'e karşı sınırdan eylem düzenleme kapasitesini kaybetmiş, işgal altındaki topraklarla bağlantısı azalmış, yaşadığı iç bölünmelerin de etkisiyle giderek zayıflamıştır. 1987'de İntifada'nın başlaması bu durumu değiştirecek, 1993'te İsrail ile FKÖ arasındaki Oslo Mutabakatı'na giden yolu açacaktır. Ancak Oslo'nun başarısızlığı, İsrail-Filistin barışına yönelik umutların giderek kaybolduğu, çatışma ve ayaklanmaların yeniden başladığ 1 , Filistinliler arasında bölünmelerin, Hamas ile El Fetih arasında iki başlılığın yaşandığı bir sürece neden olacaktır. Arap-İsrail çatışması ise 1982'den itibaren yeni aktörlerle devam edecektir.

İsrail'in Lübnan'1 işgali üzerine İran, 1982'de "Siyonist işgaline karşı savaşmak için" İran Devrim Muhafızlarını Suriye kontrolündeki Bekaa Vadisi'ne göndermiştir. Burada eğitilen Lübnanlı Şiiler daha sonra Hizbullah'ın çekirdek kadrolarını oluşturmuştur (Adıbelli, 2017: 151). Arap-İsrail çatışmasının bir ürünü olan Hizbullah temelde Güney Lübnan'1 İsrail işgalinden kurtarmak, bunun yanı sıra Kudüs'ü de kurtarıp Müslüman bir yönetime kavuşturmak amacındadır (Best ve diğ., 2012: 504). Hizbullah Nisan 1983'te ABD'nin Beyrut Büyükelçiliği'ne, Eylül 1984'de Beyrut'taki Amerikan ve Fransız karargâhlarına gerçekleştirdiği intihar saldırılarıyla adını duyurmuş (eylemler İslami Cihad Örgütü adıyla üstlenilmiştir), 1984'de Amerikan ve Fransız vatandaşlarını kaçırıp rehin alma eylemlerini başlatmış, 1992 ve 1994 'de Arjantin'deki İsrail hedeflerine bombalı saldırılar düzenlemiştir (Deeb, 2013). Hizbullah'ın Arap-İsrail çatışmasındaki stratejisi, büyük ölçüde gerilla savaşına dayanmak suretiyle, Güney Lübnan'1 işgalini İsrail için hem insan hayatı hem de mali yönden pahalı bir hale getirerek İsrail askerlerini Lübnan'dan çıkarma amacına yönelikti. Bu amaçla sadece İsrail askerlerini ve müttefiklerini değil, sınır boyundaki İsrail köylerini füze saldırılarıyla hedef almıştır. Mayıs 2000'de İsrail'in bölgeden tek yanlı çekilmesini Hizbullah kendi stratejisinin sonucu olarakgörmüştür (Best ve diğ., 2012: 505). Bu gelişme, Hizbullah'ın sadece Lübnan'da değil, tüm Arap dünyasında direniş hareketi olarak saygınlığını arttırmıştır. Ancak İsrail'in Lübnan'dan çekilmesi, işgale karşı direnişinin gerekçesini ortadan kaldıracağıiçin Hizbullah'ın İsrail ile devam eden bir çatışma alanına ihtiyacı vardı. Bu çerçevede Şebaa Çiftlikleri meselesi gündeme getirilmiş, İsrail'in, Suriye'ye ait olduğunu ileri sürdüğü bu toprak parçasında işgalinin devam etmesi, Hizbullah'a İsrail ile savaşı sürdürme imkanını vermiştir.Suriye de İsrail üzerinde baskı yapabilmek için Şebaa Çiftlikleri'nin Lübnan'a ait olduğu görüşünü desteklemiştir (Best ve diğ., 2012: 485).2005'te Lübnan eski 
başbakanı Refik Hariri'nin öldürülmesiyle başlayan çalkantılı süreç, Suriye'nin Lübnan'dan çekilmesine, Suriye karşıtı Lübnanlı siyasi partilerin güçlenmesine yol açarak Hizbullah'ın konumunu da olumsuz etkilemiştir. Bu nedenle, Haziran 2006'da Hamas'ın İsrail'de tutuklu Filistinli mahkumların serbest bırakılmasını sağlamak amacıyla Gazze'de bir İsrail askerini kaçırmasından sonra Hizbullah'ın da Filistinlilerle dayanışma gerekçesiyle Temmuz 2006'da İsrail sınırını geçerek iki İsrail askerini kaçırması, Hizbullah'ın Lübnan politik sahnesinde yeniden güç kazanma arayışı ile de bağlantılı görülmüştür (Jones, 2010). Kaçırma eylemini İsrail'i iki cepheli bir savaşa zorlayarak bölgedeki stratejik dengeyi İsrail aleyhine değiştirme girişimi olarak yorumlayan ve İsrail'in 2000'de Güney Lübnan'dan, 2005'te Gazze'den tek yanlı çekilmesinin caydırıcılık kapasitesine zarar verdiğini düşünen İsrail askeri çevreleri, Hizbullah'ın eylemine kapsamlı bir operasyonla karşılık vermeyi kararlaştırmıştır (Jones, 2010). Bu çerçevede 34 gün süren Temmuz Savaşı başlamış, İsrail'in Hizbullah'ın tedarik yollarını ve destek temelini yok etmek amacıyla Güney Lübnan'daki sivil halkı hedef alması, 900 bin kişinin yerinden olmasına, 1000 civarında Lübnanlı sivilin ölümüne neden olmuştur. Ateşkes sağlandığında Hizbullah zafer kazandığını duyurmuşsa da,savaşın bedeli çok ağır olmuş, Lübnan'ın maddi kaybı dört trilyon ABD dolarını bulmuştur (Best ve diğ., 2012: 486487).

\subsection{Arap-İsrail Çatışmasını Sonlandırmaya Yönelik Girişimler}

Arap-İsrail anlaşmazlığını çözüme kavuşturmak amacıyla pek çok barış planı gündeme getirilmişse de, tüm tarafların müzakere masasına gelmesini sağlayabilecek koşullar, 1990'da Soğuk Savaş'ın bitmesi ve Körfez Krizi'nin bölgede yarattığı uygun atmosferde ortaya çıkmıştır.Arap-İsrail çatışması Soğuk Savaş'ın en önemli mücadele alanlarından biri olmuş ve büyük güçlerin farklı devletlerin yanında yer almaları, çözüm için gerçek bir adım atılmasını önlemişti. "Dünyanın başka yerlerindeki paralel barış süreçleri için olduğu gibi, Ortadoğu barış süreci için de, Soğuk Savaşın bitmesi gerekiyordu” (Lewis, 2015: 461).

Körfez Krizi, ABD’nin Soğuk Savaş’tan sonra nüfuz mücadelesinde rakipsiz kaldığının en önemli göstergesiydi ve Ortadoğu'da parametrelerini tek hegemonik güç olarak belirleyeceği bir süreci işaret etmekteydi. Körfez Krizi sırasında ABD’nin önemli Arap ülkelerinin desteğini sağlayabilme firsatını elde etmiş olması ve İsrail ve FKÖ’nün zayıflayan siyasi konumları, 1991'de Madrid'de, İsrail ve Arap ülkeleri ile Filistinlilerin barış müzakerelerine başlamalarına imkan tanımıştır. ABD ve SSCB'nin ortak desteğinde gerçekleştirilen Ortadoğu Uluslararası Barış Konferansı, İsrail'i henüz tanımamış komşu Arap devletleri Suriye, Lübnan, Ürdün ve Filistinliler (İsrail'in FKÖ ve Doğu Kudüs ile bağlantılı Filistinliler ile görüşmeyi kabul etmemesi nedeniyle, Filistinliler konferansa Ürdün ile ortak heyet halinde katılmıştı)ile İsrail'i barışı müzakere etmek için ilk kez bir araya getirmekteydi (Cleveland, 2015: 548). Konferansla sadece ikili sorunların değil, bölgesel sorunların da ele alınması ve kapsamlı bir Ortadoğu barışının sağlanması hedeflenmiştir. Bu çerçevede, iki taraflı ve çok taraflı olmak üzere iki kola ayrılan görüşmelerle, İsrail ile Suriye, Lübnan, Ürdün ve Filistin arasında ayrı ayrı barış anlaşmaları yapılması, ayrıca su ve çevre sorunları, silahların denetimi, mülteciler ve ekonomik kalkınma gibi daha geniş bölgesel sorunların çözülmesi amaçlanmıştır (Best ve diğ., 2012: 480). Uzun bir süreye yayılarak belli aralıklarla yapılan görüşmelerde somut bir ilerleme kaydedilememişse de, İsrail ile FKÖ arasında 1993'te Oslo Anlaşması'nın imzalanmasına giden yol açılmıştır. Oslo Anlaşması, 1994'de Ürdün-İsrail barış anlaşmasının imzalanmasına imkan verecek, Suriye ve Lübnan ile İsrail arasındaki görüşmelerden ise sonuç alınamayacaktır. Bununla birlikte, Suriye-İsrail görüşmeleri Ocak 2000'deki doğrudan görüşmeler başarısızlıkla neticelenene kadar ABD gözetiminde devam etmiştir. 2003'te Türkiye'nin arabuluculuk girişimleri gündeme gelmiş, 2004-2006 arasında bir Avrupalı arabulucu kanalıyla gayri resmi görüşmeler yapıldığı iddia edilmiş, 2007'de taraflar görüşmelere yeniden başlama iradesini ortaya koyunca Türkiye'nin arabuluculuğu yine söz 
konusu olmuş, ancak Mayıs 2008'deki dolaylı görüşmelerden sonra Aralık 2008'de İsrail'in Gazze operasyonunu protesto eden Suriye'nin çekilmesi üzerine doğrudan görüşmeler yapılamamış, Mart 2009'da iktidara gelen Netanyahu hükümeti ise görüşmelere yanaşmamıştır (Yeşilyurt, 2013: 419-420).

Arap-İsrail anlaşmazlığının çözümüne yönelik diğer bir önemli girişim, 2003'te ABD, Rusya, BM ve Avrupa Birliği'nin oluşturduğu Ortadoğu Dörtlüsü (Quartet) tarafindan hazırlanan Yol Haritası olmuştur. Yol Haritası; 1967'de başlayan işgali sona erdirmeyi, mülteci meselesine adil ve gerçekçi bir çözüm bulmayı, İsrail-Filistin anlaşmazlığının yanı sıra İsrail ile Lübnan ve İsrail ile Suriye'yi de içerecek şekilde kapsamlı bir barış sağlamayı öngörmektedir. Üç aşamalı olan Yol Haritası'nın son aşamasında nihai sınırlarıyla bağımsız bir Filistin devletinin kurulması amaçlanmaktaydı (Arı, 2007). Oslo'dan farklı olarak bir nihai hedef ortaya konulmakla birlikte, Yol Haritası da Oslo'da olduğu gibi, öncelikle İntifada'nın sonlandırılmasına ve İsrail'in güvenlik sorununu çözmeye odaklanmıştı (Arı, 2007). Yol Haritası, 2007'de düzenlenen Annapolis Konferansı'yla uygulamaya geçirilmiş, ancak İsrailFilistin doğrudan görüşmelerinde ilerleme sağlanamamış, Arap-İsrail kanalında ise somut bir adım atılamamıştır.

Aralık 2010'da Tunus'ta başlayıp, kısa zamanda bölgeye yayılan, Tunus, Mısır, Libya ve Yemen'de iktidar değişikliklerine, Suriye'de ise uzun ve kanlı bir iç savaşa yol açan Arap Baharı,İsrail'in barış müzakerelerine yönelik tutumunu olumsuz şekilde etkilemiştir. İsrail, Arap Baharı'nı İsrail ve Batı karşıtı İslameı bir dalga olarak nitelendirmiş, Arap demokrasilerinin politik İslamın yükselişine yol açacağını değerlendirmiştir. Hamas, Hizbullah ve İran ile olan tecrübeleri İsrail'e yönelik İslamcı düşmanlığın kanıtlarıydı ve bölgede başka İslamcı partilerin iktidara gelmesi İsrail için büyük problemler yaratabilirdi (Dessi, 2012).

İsrail, ABD’ye karşı yıllarca kullandığı, diktatörlüklerle kaplı bir denizde demokrasi adası olduğu, demokrasinin gerçek bir barış için hayati olduğu (Byman, 2011) görüşünü Arap Baharı'yla birlikte bir kenara bırakmışa benzemekteydi. Esasen barış anlaşmalarını diktatörlüklerle imzalayan ve bu rejimlerin, halklarının duyarlılıklarını dikkate almaması sayesinde ciddi bir tehdide maruz kalmadan güvenliğini sağlayan İsrail, değişimden değil, statükodan yanaydı (Byman, 2011).İsrail, İslamcıların iktidara gelmesinden kaygı duyduğunu belirtse de, gerçekte halkın taleplerine duyarlılık gösterecek demokratik yönetimlerin iş başına gelmesinden endişe etmiştir. Arap Baharı İsrail'i, bölgedeki ve Filistin topraklarındaki uygulamalarına gözlerini kapamayan Arap kamuoyu ile karşı karşıya getirmiştir.

İsrail, geleceğini öngöremediği bir bölgede, geleceğini öngöremediği liderlerle barış yaparak güvenliğini riske atmak istememektedir. Suriye iç savaşına İran ve Hizbullah'ın da rejimin yanında yer alarak dahil olması, İsrail'in endişelerini yoğunlaştırmıştır. ABD'nin etkin liderlik gösteremediği, Rusya'nın yeniden bölgeye geldiği bir konjonktürde barış beklentileri, yerini güç dengelerini değiştirme mücadelesine bırakmıştır.

\section{SONUC}

Arap-İsrail çatışmasının bölgede büyük bir yıkıma yol açtığını belirtmek yanlış olmayacaktır. Üç büyük savaş, bölge ülkelerine dağılmış milyonlarca Filistinli mülteci, işgal, iç savaş, kaynakların silahlanmaya ayrılmasının getirdiği ekonomik sorunlar, istikrarsızlık, radikalleşme, terör, dış güçlerin nüfuz alanlarına bölünme, kamplaşma ve düşmanlıklar Ortadoğu'nun son 70 yıllık tarihini şekillendirmiştir.

İsrail'in dış güçlerin desteğiyle ve Filistinlilerin hakları göz ardı edilerek kurulduğu inancı, Arapların İsrail'e yaklaşımlarındaki temel unsur olmuştur. İngiltere'nin Yahudi milli yurdunu kurarken, ulusal haklarını tanımadığı Filistinlilerin bağımsızlık mücadelesini bastırması, Siyonistlerin Yahudi göçlerini ve toprak alımlarını organize ederek Filistin 
topraklarını sistemli şekilde ele geçirme politikası izlemesi, ABD ve SSCB'nin stratejik hesaplarla BM'nin taksim kararını desteklemesi, Filistinlilerin yüzyıllardır yaşadıkları topraklarından koparılmaları sonucunu doğurmuş ve Arapların toplumsal hafizasına kazınmıştır.

Kuruluşundan itibaren İsrail'e sağlanan ABD desteği, İsrail'in Filistin ve Arap topraklarını işgal ve ilhak etmesi, topraklarını giderek genişletmesi, yerleşim politikalarıyla Filistinlilerin topraklarını "yutması", BM kararlarını hiçe sayması, Batı dünyasının İsrail söz konusu olduğunda çifte standartlı bir yaklaşım benimsemesi, İ́srail’e karşı olumsuz duyguların hala güçlü olmasının ana nedenleridir.

İsrail-Filistin anlaşmazlığı; Arap ve Müslüman kamuoyunu radikalleştirmekte, ABD ve Batı düşmanlığını körüklemekte, terör gruplarına eylemleri için gerekçe sağlamakta, 1lımlı rejimlerin Batı yanlısı politikalara destek vermelerini engellemekte, İran'ın anlaşmazlığı kendi bölgesel amaçları için istismar etmesine yol açmaktadır.

Arap devletlerinin, 1948'den itibaren Filistin mücadelesinin liderliğini üstlenmeleriyle başlayan Arap-İsrail anlaşmazlığı, Mısır'ın 1979'da İsrail ile barış yapmasından sonra hızını kaybetmiş, ancak sonlanmamıştır. Mısır'1 1994'de Ürdün takip etmişse de, Ürdün-İsrail barışı, İsrail ile FKÖ'nün 1993'te Oslo Anlaşması'nı imzalamasından sonra mümkün olabilmiştir. Filistin meselesi pek çok Arap ülkesi bakımından İsrail ile ilişki kurmanın ön koşulu olmayı sürdürmektedir. Dolayısıyla İsrail'in Arap ülkeleriyle ilişkilerinde tam normalleşme sağlanamamış, ilişkilere daha ziyade "ne savaş ne barış" durumu hakim olmuştur. 70 yıllık mevcudiyetine rağmen İsrail bölgeye entegr olamamış, "yabancı bir unsur" olarak görülmeye devam edilmiştir. Arap Baharı, İsrail'e imzaladığı barış anlaşmalarının ne kadar kırılgan bir temele dayandığını göstermiştir.

İsrail'in 1982'deki Lübnan işgalinden sonra Arap-İsrail anlaşmazlığının tarafları değişmiştir. İran'ın ve Suriye'nin desteğiyle giderek güçlenen Hizbullah'ın, işgale karş1 gerçekleştirdiği “'meşru direniş eylemleri”, bu örgütün sadece Lübnan'da değil, Arap sahasında da önemli bir güç olarak görülmesine yol açmıştır.

Bu kez ön planda Hizbullah ve Hamas'1n, arka planda ise İran ve Suriye'nin yer aldığı direniş ekseni ile El Fetih, 1lımlı Arap ülkeleri ve İsrail'in açık ya da zımni mutabakat halinde oldukları 1lımlı eksen arasında yeni bir cepheleşme görünümü ortaya çıkmıştır. Bölgesel güç dengelerini değiştirmeyi amaçlayan bu cepheler arası mücadelede Filistin meselesi çoğu kez olduğu gibi, politik bir araç olarak kullanılmaktadır. ABD'nin etkin liderlik gösteremediği ve Rusya'nın Suriye iç savaşına müdahil olarak dengeleri etkilemeye başladığı bir konjonktürde Filistin-İsrail ve Arap-İsrail sorununun barışçı çözümünü beklemek gerçekçi görünmemektedir. 


\section{KAYNAKÇA}

ADIBELLİ, B., 2017, Pax Persica: Iran Jeopolitiği, IQ Kültür Sanat Yayıncılık, İstanbul.

ARI, T., 2007, “Filistin'de Kalıcı Barış Mümkün mü?”, Akademik Orta Doğu, 2 (1), 11-34.

ARMAOĞLU, F., Filistin Meselesi ve Arap-İsrail Savaşları (1948-1988), Türkiye İş Bankası Kültür Yayınları, Ankara.

ARMAOĞLU, F., 1991, 20. Yüzyıl Siyasi Tarihi, Cilt:I 1914-1980, Türkiye İş Bankası Kültür Yayınları, Ankara.

ARURİ, N.H., 1972, Jordan: A Study in Political Development (1921-1965),Martinus Nijhoff, The Hague.

BEST, A., JUSSİ, M.H., JOSEPH, A.M., KİRSTEN, E.S., 2012, 20. Yüzyılın Uluslararası Tarihi(Çev. Taciser Ulaş Belge), Siyasal Kitabevi, Ankara.

BYMAN, D.,2011, "Israel's Pessimistic View of the Arab Spring”, The WashingtonQuarterly, 34 (3).

DEEB, M., 2013, Syria, Iran, and Hezbollah: The Unholy Alliance and its War on Lebanon, Hoover Institution Press, Stanford.

DESSİ, A., 2012, "Israel and Palestinians After the Arab Spring: No Time for Peace", Instituto Affari Internazionali, IAI Working Papers 12/16-May 2012, pubblicazioni.iai.it/pdf/DocIAI/iaiwp1216.pdf

CLEVELAND, W.L., 2015, Modern Ortadoğu Tarihi(Çev. Mehmet Harmanc1),Agora Kitaplığı, İstanbul.

ELPELEG, Z., 1993, The Grand Mufti: Haj Amin Al-Hussaini, Founder of the Palestinian National Movement, Psychology Press.

FAHREDDİN, M. ve Çalışkan, K., 2000, "Yeni İntifada ve Filistin Sorununun Kısa Tarihi”, Birikim, (140): 20-35.

JONES, C., 2010, “Introduction”, Jones, C. ve Catignani, S. (Eds.),Israel and Hezbollah: An Asymmetric Conflict in Historical and Comparative Perspective, Routledge.

KHALAF, I., 1991, Politics in Palestine: Arab Factionalism and Social Disintegration, 19391948, State University of New York Press, New York.

KHALIDİ, R., 2006, The Iron Cage: The Story of the Palestinian Struggle for Statehood, Beacon Press, Boston.

KHOURİ, F.J., 1985,The Arab-Israeli Dilemma, Syracuse University Press, New York.

KİMMERLing, B. ve Migdal, J.S., 2003, The Palestinian People: A History, Harvard University Press, Cambridge.

KÖPRÜLÜ, N., 2009, “Arabizmden Teritoryal Kimliğe Geçiş: 1989 Sonrası Ürdün'de Kimlik Politikaları ve Demokratikleş(eme)me Çabaları", İ.Ü. Siyasal Bilgiler Fakültesi Dergisi, (41): 195-214.

KUMARASWAMY, P.R., 2009, The A to Z of the Arab-Israeli Conflict, Scarecrow Press, Maryland.

KÜRKÇÜOĞLU, Ö., 1982, Osmanlı Devleti’ne Karşı Arap Bağımsızlık Hareketi (1908-1918), Ankara Üniversitesi Siyasal Bilgiler Fakültesi Yayınları, Ankara. 
LEWİS, B., 2015, Ortadoğu-İki Bin Yıllık Ortadoğu Tarihi(Çev.Selen Y. Kölay), Arkadaş Yayınevi, Ankara.

RABINOVICH, I. ve BRUN, I., 2017, Israel Facing a New Middle East: In Search of a National Security Strategy, Hoover Institution Press, Stanford.

SAYIGH, Y., 1997, Armed Struggle and the Search for State: The Palestinian National Movement, 1949-1993, Clarendon Press, Oxford,

SHEMESH, M., 1996, The Palestinian Entity1959-1974, Arab Politics and the PLO, Frank Cass, London.

SHLAIM, A., 2007, Lion of Jordan. The Life of King Hussein in War and Peace, Penguin Books, London.

SUSSER, A., 1994, “Jordan, the PLO and the Palestine Question”, Nevo, J. ve Pappé,I.(Eds.), Jordan in the Middle East 1948-1988, The Making of a Pivotal State, Frank Cass, 212228.

YEŞİLYURT, N., 2013, “Orta Doğu'yla İlişkiler”, Oran, B.(Ed.),Türk Dış Politikası-Kurtuluş Savaşından Bugüne Olgular, Belgeler, Yorumlar (Cilt III. 2001-2012), İletişim Yayınları, Ankara,401-462.

YILMAZ ŞAHIN, T., 2016, Uluslararası Politikada Orta Doğu, Barış Kitap, Ankara. 